\title{
Pattern of Corporate Social Responsibility (CSR) in Mahakam Ulu Regency, East Kalimantan
}

\author{
Adi Wijaya ${ }^{1} \quad$ Mursidah Nurfadillah $^{2} \quad$ Dio Caisar Darma $^{3 *}$ \\ 1.Program of Economics Master, Faculty of Economics and Business, Mulawarman University, Tanah Grogot \\ Street (1), Gn. Kelua, Samarinda City, East Kalimantan, PO. Box 75117, Indonesia \\ 2.Departement of Management, Faculty of School of Economics, Law, Politics and Psychology, Muhammadiyah \\ University of East Kalimantan, Ir. H. Juanda Street (15), Sidodadi, Samarinda City, East Kalimantan, PO. Box \\ 75243 , Indonesia \\ 3.Samarinda High College of Economics Science, K. H. Abul Hasan Street (77), Samarinda City, East \\ Kalimantan, PO. Box 75242, Indonesia
}

\begin{abstract}
The development of Corporate Social Responsibility (CSR) in this decade was also followed by the strengthening of the existence of CSR into normative obligations in various countries. Although only a few countries have done it, Indonesia is a part of it. In East Kalimantan Province, the problem of CSR already exists in the form of legal products that have been passed in the form of local regulations. But in fact, there are still local regulations that end up to the endorsement stage. This study is aimed at formulating the legal basis for the formation, consideration, determination and reference of the preparation of the Regional Regulation of Mahakam Ulu Regency on CSR in terms of philosophical, sociological, and juridical. The object of aggregate research is aimed at mapping the rules about corporate CSR in Mahakam Ulu Regency, so that the data collected includes primary and secondary data in 2018. The research analysis model is based on quantitative and qualitative approaches. Philosophically, there is a company's awareness of a fact or fact that exists in most communities, namely the high difference between prosperity and poverty both at the level of rural communities and the Capital District, especially in the area of Mahakam Ulu Regency. From a sociological point of view, this regional regulation is very useful in building a society that is increasingly left behind. Considering that this new area has a limited population, there has been a development imbalance, so that the dominant population is above the poverty line. In terms of legal aspects, based on policy analysis, which is related to the authority, substance, and regulated material, which indeed does not yet exist, so it is necessary to form a Regional Regulation of the Mahakam Ulu Regency regarding CSR.
\end{abstract}

Keywords: CSR; Philosophical; Sociological; Juridical; Government Regulations; Policies

DOI: $10.7176 / \mathrm{EJBM} / 11-31-07$

Publication date: November $30^{\text {th }} 2019$

\section{Introduction}

Corporate Social Responsibility (CSR) is an important element in the framework of sustainability), which covers economic, environmental and socio-cultural aspects. In this case, the responsibility is an important process in managing the costs and profits of business activities with stakeholders both internally (workers, shareholders, and investors) and externally (public regulatory institutions, community members, civil society groups and other companies), which is not only limited to the concept of giving donors, but the concept is very broad, not static, and passive, but is a right and obligation shared between stakeholders.

CSR is a concept that is not present instantly and is the result of a long process where the concepts and applications of this concept have now undergone many developments and changes from previous concepts. In the Asian region, the concept of CSR developed since 1998, but at that time there was not yet a good understanding or understanding of this. Meanwhile, in Indonesia the concept of CSR began to be a hot issue since 2001, where many companies and agencies have begun to look at CSR as a concept of community empowerment. At present, CSR is not only a tradition practiced by companies. The concept and existence of this activity has begun to be elevated to a higher position, not only in the scope of private companies but also has come to the attention of the public sector, namely the government.

This can be observed from the existence of global issues concerning the importance of the contribution of companies and governments in the improvement, development and protection of the environment and society which was sparked at the World Summit on Sustainable Development (WSSD) in Johannesburg, South Africa in 2002 which emphasized the importance of responsibility corporate social.

The development of CSR in this decade was also followed by the strengthening of the existence of CSR into obligations that were normative in various countries. Although only a few countries have the courage to take such action, Indonesia is one of the countries in it. This result is a very positive development for the agenda itself.

From a philosophical aspect, CSR in Indonesia has been embedded in the soul of the Pancasila and the 1945 Constitution of the Republic of Indonesia. In opening the regulation, it is clearly implied that the purpose of the nation and state. The state must protect all citizens, realize public welfare, educate the nation's life and participate 
in carrying out world order. This relates to the national economy and social welfare, must be regulated by the state and for the greatest prosperity of the people.

Article 33 (paragraphs 1,2, 3, and 4) states that the economy is structured as a joint effort based on the principle of kinship, production branches which are important for the state and which control the livelihoods of the people are controlled by the state, earth, water, and wealth the nature contained therein is controlled by the state and used for the greatest prosperity of the people. The national economy is organized based on economic democracy with the principles of togetherness, fair efficiency, sustainable, environmentally friendly, independent, by maintaining a balance of progress, and national economic unity (Firmansyah, 2012).

From these rules, it is clear that the economic system that is oriented together, the use of natural resources, and the environment for social welfare is explicitly a commitment of the constitution in Indonesia. Therefore, the nature of CSR in Indonesia which was initially voluntary became mandatory for companies to carry out CSR programs.

In East Kalimantan Province, the problem of CSR already exists in the form of legal products that have been passed in the form of local regulations. But in fact, there are still local regulations that end up to the endorsement stage. That is the Regional Regulation of the Province of East Kalimantan Number: 3 of 2013 concerning Corporate Social Responsibility.

As a potential, CSR should be juxtaposed with local government programs relating to the implementation of social and environmental programs. CSR arrangements in the form of Regional Regulations aim to provide a legal basis, and to create sustainable economic development in the Mahakam Ulu Regency in order to improve the quality of life and the environment that benefits the local community, the community, companies, or the business world, and individuals themselves in order to establish relationships harmonious, balanced, in accordance with the environment, values, norms, and culture of the local community.

The company is not an entity that only operates for its own interests but must also provide benefits for shareholders, creditors, consumers, suppliers, government, society, analysts, and other parties. Therefore, the government is obliged that companies or businesses participate in the success of government programs, by providing benefits to the community through integrated program synergies. Through synergized cooperation between the government, the private sector and the community, assistance provided by the company (in the form of money, goods, programs can be right on target, and respond to community needs).

In general, the problem is that Mahakam Ulu Regency does not yet have rules that govern overall CSR issues, the regulation is still partial. Meanwhile, empirical practice shows that CSR has been carried out by various companies, both legal entities, non-legal entities, and individuals who have provided benefits. Therefore, orderly CSR needs to be regulated in Regional Government Regulations in accordance with the authority of the Mahakam Ulu Regency, bearing in mind that CSR is a potential and resource for the implementation of non-budget social welfare and Regional Expenditure Revenues that can be used to improve the capability, care and social responsibility of the business world. in the implementation of sustainable social welfare.

In detail the problems that arise in the effort to formulate Regional Regulations in accordance with the Law of the Republic of Indonesia Number: 12 of 2011 emphasize the importance of philosophical, sociological, and juridical rationales or arguments in the formation of a rule, not much different from the Regional Regulation of the Mahakam Ulu Regency Government.

\section{Method}

2.1. Research Design

The research design is based on the preparation of academic texts in the Regional Regulation on Corporate CSR in Mahakam Ulu Regency and tries to answer practical questions including:

- Formulate the legal basis for the formation of a Regional Regulation on CSR.

- Formulate the basis for the consideration of establishing a Regional Regulation on Corporate CSR.

- Formulate the main target of the enactment of a Regional Regulation on CRS.

- Compile references or references for the preparation and discussion of CSR.

\subsection{Data Collection}

The object of aggregate research is aimed at mapping the rules about corporate CSR in Mahakam Ulu Regency. What is the position, purpose and objectives of managing this policy, to reporting CSR activities by the implementer. 


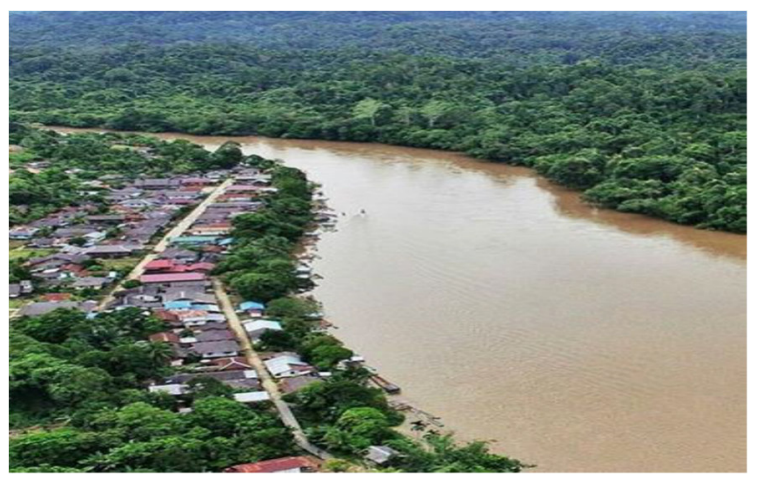

Figure-1. Research Area

Data collected includes primary data and secondary data. Primary data was generated from interviews and Focus Group Discussion (FGD) on officials, the community, business people, and the government. Then, other data are generated from the answers to the questionnaire. The primary sources of secondary data are the Regional Development Planning, Research and Development Agency, the Legal Section of the Regional Secretariat, and the Central Statistics Agency of Mahakam Ulu Regency. Ways of collecting data in this study include: (1) Interviews; (2) FGD; (3) Survey; and (4) secondary data collection or documentation in 2018.

\subsection{Data analysis}

The first analysis is a qualitative analysis that accommodates respondents' perceptions from interviews and FGDs. Respondents' perceptions are summarized to produce meaningful findings. Second, namely quantitative analysis is carried out by utilizing data collected from the descriptive research stage. The approach used is descriptive statistics grouped into:

- Calculations to provide an overview of data development, namely the difference in data, average, growth, and proportion.

- Drawing conclusions from the quantitative data presented.

\section{Results and Discussion}

\subsection{Philosophical Basis}

Law of the Republic of Indonesia Number: 12 of 2011 along with its explanation regulates that Pancasila is the source of all sources of state law. The explanation of the article states that placing Pancasila as the basis and ideology of the state as well as the philosophical basis of the state so that any material contained in the regulations must not conflict with the values contained in Pancasila.

Establishment of Regional Regulation Plan for Mahakam Ulu Regency regarding CSR for the Company and the business world philosophically in the context of achieving the objectives of the State and based on the basis of the Pancasila of the Republic of Indonesia. That is, intended for the maximum prosperity of the people. The importance of this regional regulation must be based on the company's awareness of a fact or fact that exists in the majority of the community, which is a quite striking difference between prosperity and poverty, both at the level of rural communities, and the Capital District in the Mahakam Ulu Regency.

Therefore, social responsibility is mandatory or not, this must be the commitment and care of the large corporate actors and are able to reduce the gap due to poverty that afflicts most of the residents. The purpose of CSR is also based on a sense of humanity. However, it is also not solely for the foundation of humanity but the continuity of business which ultimately creates social justice that is evenly distributed among the Mahakam Ulu community.

\subsection{Sociological Basis}

The development of an increasingly complex era in the dynamics of social interaction of the world community has brought implications for the development of issues and problems in various fields of life. The necessities of life for the community have also increased, while the increase in the number of residents has also continued to advance from year to year. To meet the needs of the population, we need a strategy that is able to support the fulfillment of the needs of residents of an area, including the Government of Mahakam Ulu Regency.

The population of Mahakam Ulu Regency is 28,518 people. Of these, some are below the poverty line until September 2017 based on data obtained from the Central Statistics Agency in 2018 which has reached 16.21\%. The picture shows that poverty is still a separate problem faced by the Regional Government of Mahakam Ulu Regency.

There are quite a number of companies in the Mahakam Ulu Regency which are quite large and able to participate in thinking about the poverty alleviation problems that occur. In principle, a company is a private 
institution established with capital whose main purpose is to make a profit. This is often the reason for companies to conduct business activities without regard to moral values and business ethics. Thus, the company's operations cause various social problems. Such as social inequality, causing uncomfortable environmental impacts, waste of use of natural resources, inequality between producers and consumers.

Inequality in bargaining positions between companies and employees. In fact, without realizing it, the company has carried out a widespread denial of human dignity, and environment. From the other side, the interaction between the company and the community socially is getting closer. The company has entered and influenced all lines of community life. In addition to being a business institution, companies have also become part of corporate citizenship who are directly involved in the dynamics of society.

The sustainability of the company's business is also very dependent on economic conditions and the quality of life of the people. Companies must not only seek profit, but must also participate in paying attention to environmental sustainability and care for the social problems facing society (profit, people, planet).

\subsection{Juridical Basis}

Local regulations regarding CSR are formed to overcome legal problems or fill legal vacuum by considering existing rules, in order to ensure legal certainty and a sense of community justice. Based on the analysis of the Laws and Regulations, as described in the previous section, which relates to the authority, substance or regulated material, which indeed does not yet exist, so it is necessary to form a Regional Regulation of the Mahakam Ulu Regency regarding CSR. This rule is recognized as or is:

- Regulations for the implementation of several laws of the Republic of Indonesia and Government Regulations in accordance with the authority of the Government of Mahakam Ulu Regency.

- The basis for further regulating and strengthening the Regional Regulations of the Mahakam Ulu Regency include investment, environment, marine and fisheries.

- The legal basis provides guidance, supervision, enforcement of administrative sanctions, and coordinates the implementation of CSR.

\subsection{The Concept of CSR Implementation}

The practice of the business world in the past which tends to have a negative impact makes the discourse about corporate social responsibility or better known as CSR into the need to change the image of an environmentally friendly business world. Business people not only control the market but also control the stakeholders who determine the survival of the company. As a company, they realize that they are part of their environment that needs to be well cared for to live together in a sustainable way.

There really isn't a single definition of CSR or corporate social responsibility. ISO 26,000 defines CSR as an organization's social responsibility for the impact of its decisions or activities on society and the environment through transparent and ethical behavior, consistent with sustainable development and community welfare, taking into account the interests of stakeholders, according to applicable laws and consistent with norms international norms, integrated in all organizational activities, in this sense encompassing both activities, products and services.

Meanwhile, the World Bank defines CSR as a business actor to contribute to sustainable economic development together with workers, families, local communities and the wider community to improve their lives through ways that benefit business and development.

If we trace the origins of the term and implementation of CSR, it actually comes from western countries such as the United States (Bartens, 2000) and the European Union (Bowen, 2013). Although in Asian countries like Indonesia have implemented CSR in different forms and ways carried out by state-owned or regional companies. The philosophy of the concept of CSR in western countries with Indonesia is indeed different where in western countries that glorify the rule of law is based on individualistic capitalism that prioritizes individual interests.

Individual or business awareness to carry out CSR has been formed from within, so it is true that the character of CSR is more voluntary, not mandatory. Awareness to maintain a balance between business, environment and social society makes businesses more sustainable which is not just profit seeking which is temporary, but still prioritizes the principle of sustainable development. The existence of CSR has been responded to positively and there has been almost no upheaval.

On the contrary, it is very different from the existence of the concept of corporate social responsibility in Indonesia. The basic philosophy is very different which prioritizes the principle of kinship as stated in the Preamble of the 1945 Constitution of the Republic of Indonesia (Paragraph IV). At the level of practice, there is a lot of indifference of business actors to the environment and social. Massive exploitation of natural resources had occurred massively in the Suharto regime, until the 2000s (the reform era). Social conditions also have never received the attention of business actors who are considered to be the domain of state functions.

Therefore, when the concept of CSR was adopted in Indonesia, turmoil arose between business actors and the academic sphere of debate. The main issue is whether CSR is mandatory or not or if it is legally discussed, whether CSR needs to be regulated in legislation or not. Therefore, our way of thinking in understanding this 
concept must be returned to the constitution in which it involves the duties and functions and authority of the state. At that level, CSR arrangements have been regulated in various regulations such as: Law of the Republic of Indonesia Number: 25 of 2007 concerning Investment for Limited Liability Companies, Law of the Republic of Indonesia Number: 40 of 2007, Indonesian Government Regulation Number: 47 of 2012 concerning Limited Corporate Social and Environmental Responsibility. In the regulation, it is clearly regulated that CSR is mandatory (imperative), even though the implementation is not yet effective.

From these various laws and regulations, it is clear that the concept of CSR is actually set and stated as an obligation. However, it is still spread in various laws and regulations so that it has not been able to provide benefits for development in the Province of East Kalimantan (Indonesia), especially in the District of Mahakam Ulu. There is a need for policies governing CSR, so that the implementation of CSR can be more targeted and targeted according to the direction of the development of the Mahakam Ulu (Medium and Long-term Development Plan) in the development of the social, social economy and environment sectors. Thus it is clear that the concept of cooperative relations between government, business actors and the community is "a conditio sine quanon" which according to Albareda et,al. (2007) is described in the following slices:

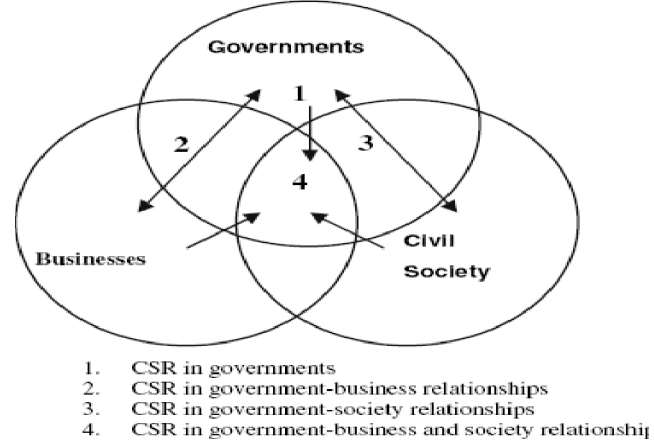

Figure-2. Relational CSR Model

The model contains the slices of the three elements. This shows the triangular nature of CSR whose implementation emphasizes the participation of three parties. Ideally, CSR activities require equitable distribution of responsibilities without any predomination by one party. The economic and legal aspects absolutely show the existence of relations between elements in the ecosystem and CSR binds the company, making the existing responsibility as an obligation that must be fulfilled. Both of these aspects have a coercive nature whose implementation is regulated legally according to the applicable law as a minimum standard given by the government to limit the free movement of companies.

The implementation of CSR is not merely subject to legal and political regulations, but needs to be considered as a supporting factor or as a harmonious bridge between the company and the environment. The consequence is that the company does not only focus on internal work such as tax matters, regulations, customs, or other matters related to the company's interests.

In the context of implementing or operating CSR, the local government must optimize the business potential that can be invited to partner to carry out CSR and care for social problems that exist in the Mahakam Ulu Regency. For example by providing a map of social problems. This basic map of social problems is very important to be used as a reference. Equality, openness and mutual benefit are the basic principles and foundation of cooperation between the government, the business world, and society.

Equality means mutual trust, mutual respect, mutual respect, mutual recognition of each other's abilities and authority. Openness, mutual trust, honesty, no confidentiality, and sure of each other's commitment. Mutual benefit, which means getting mutual benefits with reduced social problems, means the government has succeeded in overcoming the problems that exist in each environment. Besides that, the business world also receives social support because of its existence, it gets government and community support. The key to success in partnership is of course the existence of harmonious joint commitment and harmonious collaboration, far from the elements of pressure because it has built a climate of mutual trust between the partners involved. In this level, reference is needed in the form of regulations or laws governing CSR.

With reference to the principle of independence, the implementation of CSR is still left to the business actors themselves, namely by giving freedom for business actors to carry out CSR, but still in the corridor or in accordance with the direction and objectives of the development policy of Mahakam Ulu Regency. Thus, the state has two functions at the same time, namely the regulator and facilitator. Through the principle of independence, businesses are also given the freedom to jointly through a CSR forum to compile the Company's Annual Work Plan, determine target communities and CSR activities programs, obtain legal certainty and legal protection, obtain open information, obtain services, including incentives, facilities, or to get award facilities from the Regional Government of Mahakam Ulu Regency based on the Company's compliance in implementing CSR.

Mahakam Ulu Regency is a division area of West Kutai district by having Ujoh Bilang village to become the 
Capital of Regency which has been inaugurated since 2013 based on the Law of the Republic of Indonesia Number: 2 of 2013 concerning the establishment of the Mahakam Ulu Regency. As a new region, that development inequality is still a serious conversation in the community, because we see that there are still many poor people in Mahakam Ulu Regency, marked by many people who still lack food and many people who still find it difficult to meet their basic needs and their many unemployment. This indicates that social problems in Mahakam Ulu Regency still need serious attention from the government.

Through CSR, the welfare and socio-economic life of the people of Mahakam Ulu Regency will be more secure. This condition, in turn, will guarantee the smooth running of the entire process or activity of the company's production and marketing of the company's production results. Maintaining environmental and natural preservation in addition to ensuring the smooth production process, it also ensures the availability of supply of raw materials produced from nature. If CSR is truly carried out effectively, it can strengthen or increase the accumulation of social capital in order to improve the welfare of society. Social capital, including its elements such as trust, cohesiveness, altruism, mutual cooperation, networking, and social collaboration have a great influence on economic growth.

With a variety of mechanisms, social capital can increase a sense of responsibility towards the public interest, broadening participation in the democratic process, strengthening community harmony, decreasing levels of violence, and crime. Corporate responsibility for the public interest can be realized through the implementation of CSR programs that are sustainable and touch directly aspects of people's lives. Thus the realization of CSR programs is an indirect company contribution to strengthening overall social capital. Unlike the case with financial capital that can be quantified, social capital cannot be calculated with certainty. However, it can be stressed that the expenditure for CSR programs is a corporate investment to foster social capital. Sustainability of the Regional Government's CSR Program Mahakam Ulu Regency requires mapping of social problems. Therefore, the government through each institution is expected to have mapped social programs, so that CSR programs can be implemented transparently, integrated and can be accounted for.

Build the principle of independence, businesses make Annual Work Plans related to CSR programs. From the plan, then juxtaposed with social and environmental development programs in Mahakam Ulu that are adjusted to the Medium and Long-Term Development Plan. Business actors who have carried out CSR well are provided with facilities in the form of tax reductions, ease of service, relief of import duties, and other awards.

The novelty research is a development and is based on previous studies by Robins \& Krosinsky (2008) concerning sustainable investing is an investment discipline that explicitly considers future social and environmental trends in financial decision making, in order to provide the best risk-adjusted and opportunitydirected returns for investors. By anticipating these trends ahead of the market, sustainable investing seeks to identify "predictable surprises" that can help ensure shareowner value over the long-term. We also take a look at what some might call the grandfather of behavioral and long-term investing, John Maynard Keynes, and whose turbulent experience as a market practitioner contributed powerfully to his prescriptions for the reform of capitalism in the Great Depression, and how that relates to current times. We propose two hypotheses - the "reasonable person hypothesis", and the "resilient markets hypothesis" - in place of the ideals of efficiency and rationality as a more durable basis for investment success. And with evidence mounting that sustainable investing offers the best chance of outperformance in the modern age, we then move to a review of the barriers that remain to incorporation by any investor, and what strategies could be considered towards encouraging maximum adaptation accordingly.

Curran \& Moran (2007) with the paper examines whether corporate financial performance is affected by public endorsement of environmental and social performance. Event study methodology, which relies on the notion of market efficiency, is used to examine the relationship between positive and negative announcements and changes in share prices or daily returns. Inclusion in and deletion from the FTSE4 Good UK Index is used as a proxy measure for good (poor) corporate social responsibility. The abnormal or unexpected daily returns associated with an event are calculated and their significance tested. The results show a trend towards positive and negative announcements having the expected effects on daily returns. But these movements are not significant and the data do not suggest that a firm's presence on the index brings it any significant financial return for signalling its corporate social responsibility.

\section{Conclusion and Suggestion}

The purpose of compiling a concept in the Regional Regulation on CSR in order to provide legal certainty and protection for the implementation of this program in Mahakam Ulu Regency and provide direction to all companies and all stakeholders in implementing CSR programs. This pattern has been prepared with various considerations, one of which is to realize the improvement of people's welfare as the goal of regional autonomy, regional governments are obliged to explore regional potentials, and the potential of business entities that are partners of regional governments that also have the obligation to apply the principles of social and environmental responsibility companies to work together with local governments to empower communities. 
Another consideration is to increase corporate awareness of the implementation of social, economic and environmental responsibility in realizing the company's commitment to participate in sustainable economic development in order to improve the quality of life and the beneficial environment regarding CSR.

In order to realize the implementation of corporate CSR in Mahakam Ulu Regency, several suggestions are given as follows:

- Schedule a discussion of the draft local regulation on CSR of companies in Mahakam Ulu Regency, given the importance of this rule.

- Coordinate with various parties in ensuring the implementation of CSR in Mahakam Ulu Regency, including: (1) Immediately forming CSR Forums from various companies, as a forum for communication, consultation and evaluation of social, economic and environmental responsibility organizers; (2) Regional Governments coordinate with companies to immediately compile, organize, design, and carry out CSR activities in accordance with the principles of social responsibility of the business world by taking into account the policies of the Regional Governments and the provisions of applicable policy regulations; (3) The Government of Mahakam Ulu Regency submits priority scale programs as material in planning CSR programs to the CSR implementing forum.

- Before the issuance of local regulations governing CSR, it is necessary to first determine the political will of the government of Mahakam Ulu Regency regarding the position or status of the importance of implementing CSR in Mahakam Ulu Regency.

- To form an appropriate regulation on corporate CSR in Mahakam Ulu Regency must be based on an academic draft of a regional regulation, because a step must be right on target, as desired from the establishment and enactment of the regulation. This policy must go through in-depth assessments conducted through in-depth research processes on a regional regulation.

\section{References}

Albareda, L., Lozano, J. M., \& Ysa, T. (2017). "Public Policies on Corporate Social Responsibility: The Role of Governments in Europe". Journal of Business Ethics, 74(4), 391-407.

Bertens, K. (2000). "Etika Bisnis Menjadi Urusan Siapa". Jakarta: Pusat Pengembangan Etika, Universitas Atmajaya.

Bowen, H. R. (2013). "Social Responsibilities of the Businessman". Iowa, USA: University of Iowa Press.

Central Bureau of Statistics. (2018). "Mahakam Regency Statistics of 2018". Catalog, 1101002.6411. Kutai Barat: Regional Balance Sheet and Statistical Analysis Section.

Curran, M. M., \& Moran, D. (2007). "Impact of the FTSE4Good Index on firm price: An event study". Journal of Environmental Management, 82(4), 529-537.

Firmansyah, A. (2012). "Penafsiran Pasal 33 Undang-Undang 1945 dalam Membangun Perekonomian di Indonesia". Jurnal Syiar Hukum, 13(1), 264-288.

Indonesian Government Regulation. (2012). "Number 47 of 2012 concerning Limited Corporate Social and Environmental Responsibility". Jakarta.

Law of the republic Indonesia. (2007). "Number 25 of 2007 concerning Investment". Jakarta.

Law of the republic Indonesia. (2007). "Number 40 of 2007 concerning Limited Liability Companies". Jakarta.

Law of the republic Indonesia. (2011). "Number 12 of 2011 concerning Formation of Legislation". Jakarta.

Law of the republic Indonesia. (2013). "Number: 2 of 2013 concerning the formation of the Mahakam Ulu Regency". Jakarta.

Regional Regulation of the Province of East Kalimantan. (2013). "Number 3 of 2013 concerning Limited Corporate Social and Environmental Responsibility, and the Partnership and Community Development Program". Samarinda.

Republic of Indonesia Constitution. (1945). "Opening of Article IV on Democracy Led by Wisdom Wisdom in Representative Consultation". Jakarta.

Robins, N., \& Krosinsky, C. (2008). “After the credit crunch: The future of sustainable investing”. Public Policy Research, 15(4), 192-197.

The World Summit on Sustainable Development. (2002). "A Reporting Service for Environment and Development Negotiations". Earth Negotiations Bulletin, 22(42), 1-107. Retrieved from: http://www.iisd.ca/linkages/2002/wssd/.

\section{Acknowledgment}

The researcher expressed his gratitude for the attention given by the Dean of Faculty of Economics and Business, Mulawarman University (Prof. Dr. Hj. Syarifah Hudayah, M.Si), Rector of Muhammadiyah University of East Kalimantan (Prof. Dr. H. Bambang Setiaji), Chair of the Samarinda High College of Economics Science (Ir. H. Syahril, ASK, M.Si), and Editorial Board of International Journal of Scientific and Technological Research (IISTE). 